\title{
PEMBAHARUAN SISTEM PENDIDIKAN DI PESANTREN
}

\author{
Ahmad Syauqi Fuady \\ Pendidikan Agama Islam STIT Muhammadiyah Bojonegoro \\ syauqi.asf68@gmail.com
}

\begin{abstract}
ABSTRAK
Pondok pesantren merupakan lembaga pendidikan keagamaan asli (indigenous) Indonesia. Eksistensi pondok pesantren tidak bisa dilepaskan dari adaptasi dan pembaharuan yang dilakukandengan berpedoman "Al muhafadzah 'ala al qadim al shalih, wa al akhdzu bi al jadid al ashlah. 'Tetap memegang tradisi yang positif, dan mengimbangi dengan mengambil hal-hal baru yang positif. Respons pondok pesantren terhadap perubahan dan dinamika zaman berbeda-beda. Umumnya perubahan dalam pondok pesantren berlangsung dalam tahapan yang pelan dan sukar diamati. Kyai memegang peran penting dalam proses pembaharuan dalam kehidupan pondok pesantren. Secara umum, para kyai mengambil sikap yang lapang dada dalam menyelenggarakan modernisasi lembaga-lembaga pesantren di tengah-tengah perubahan masyarakat Jawa, tanpa meninggalkan aspek-aspek positif daripada sistem pendidikan Islam tradisional. Setidaknya ada empat level pembaharuan dalam sistem pendidikan Islam di Indonesia, termasuk pesantren di dalamnya. Pertama, level kelembagaan. Kedua, level substansi isi kurikulumnya. Ketiga, level metodologis. Keempat, level fungsi. Dari keempat level pembaharuan tersebut, yang terjadi adalah pembaharuan pada level kelembagaan, kurikulum, dan metodologi pengajaran. Sementara pembaharuan terhadap fungsi pondok pesantren jarang sekali terjadi. Artinya pondok pesantren tetap menjadi lembaga pendidikan keagamaan sebagai tempat untuk transfer ilmu-ilmu keagamaan, mencetak ulama dan ahli agama yang tafaqquh fiddin dan mampu mengkader insan yang mutafaqquh fiddin.
\end{abstract}

Kata Kunci: Pembaharuan, Pendidikan, Pondok Pesantren. 


\begin{abstract}
Pondok pesantren is an Indonesian original religious education institution. The existence of Islamic boarding schools cannot be separated fromthe adaptation and renewal that is carried out by referring to "Al muhafadzah 'ala al qadim al shalih, wa al akhdzu bi al jadid al ashlah."The response of pondok pesantren to the changes and dynamics of the times varies. Generally, changes in Islamic boarding schools take place in stages that are slow and hard to observe. Kyai plays an important role in the process of renewal in the life of pondok pesantren. In general, the kyai took an open stance in carrying out the modernization of pondok pesantren institutions in the midst of changes in Javanese society, without leaving the positive aspects of the traditional Islamic education system. There are at least four levels of renewal in the Islamic education system in Indonesia, including pondok pesantren in it. First, the institutional level.Second, the level of substance of the curriculum content.Third, methodological level.Fourth, function level. Of the four levels of renewal, what happens is renewal at the institutional, curriculum and teaching methodology level. While renewal of the function of pondok pesantren is very rare. This means that the pondok pesantren continues to be a religious education institution as a place for the transfer of religious sciences, printing religious scholars and religious experts who are tafaqquh fiddinand capable of cadre of mutafaqquh fiddin.
\end{abstract}

Keywords: Renewal, Education, Islamic Boarding School.

\title{
A. PENDAhuluan
}

Globalisasi yang semakin mendekatkan jarak dan memperpendek waktu dengan semakin majunya teknologi komunikasi dan transportasi menciptakan dunia yang bergerak dan berubah. Tantangan, peluang, kemajuan, dan perubahan terus terjadi dalam pelabagi aspek kehidupan, termasuk pendidikan. Tentu saja, perubahan dan kemajuan yang dibawa seiring dengan globalisasi membawa persoalan, di antaranya soal akhlak dan moralitas. Oleh karenanya kemajuan iptek dan perbaikan akhlak-moral harus secara seiring sejalan menjadi pusat perhatian lembaga pendidikan. Perubahan dan pembaharuan menjadi tantangan bagi dunia pendidikan, termasuk pesantren. Pesantren sebagai lembaga pendidikan Islam tidak hanya untuk transfer of knowledge, namun juga transfer of values. ${ }^{1}$

\footnotetext{
${ }^{1}$ Hambali, "Globalisasi dan Pendidikan Pesantren” dalam Jurnal Al-Ta'lim, Vol. 13, No. 2, Juli 2014, hlm. 213-215.
} 
Perubahan merupakan keniscayaan yang pasti akan selalu dihadapi dan membutuhkan suatu pendekatan dan cara pandang baru. Sehingga perubahan itu tidak membawa kehancuran dan merobohkan hal-hal mendasar yang pernah dibangun, tetapi sebaliknya, akan makin menguatkan dan menjadikan lebih baik lagi dari sebelumnya. Dalam dunia pesantren, perubahan bukanlah hal yang asing, setidaknya itu tampak dari prinsip yang hidup dan dipegangi di pondok pesantren bahwaal muhafadzah 'ala al qadim al shalih, wa al akhdzu bi al jadid al ashlah, yaitu tetap memegang tradisi yang positif, dan mengimbangi dengan mengambil hal-hal baru yang positif.

Pembaharuan dan perubahan dalam pondok pesantren dimaksudkan agar pondok pesantren dapat menyesuaikan diri dan meresponsdinamika kehidupan sehingga bisa tetap eksis. Di samping itu, pembaharuan pesantren dapat dijadikan respons untuk menepis penilaian sebagian orang bahwa pesantren lekat dengan stigma keterbelakangan dan hanya menghasilkan lulusan yang paham fikih atau hukum Islam saja. ${ }^{2}$ Tentu saja setiap perubahan harus berjalan bertahap dan memiliki hambatan dan rintangan. Untuk mengatasi hambatan dan rintangan dalam usaha pembaharuan di pondok pesantren, Nurcholis Madjid menyarankan beberapa hal pokok sebagai berikut:

1. Perubahan pesantren harus dimulai dari dalam, karena tidak ada yang dapat memimpin perubahan pesantren kecuali "orang dalam".

2. Agar gagasan-gagasan baru dapat diterima diperlukan kepemimpinan yang legitimate, sah menurut ukuran-ukuran pesantren.

3. Perubahan yang terjadi hendaknya tidak bersifat radikal-revolusioner

4. Perubahan pesantren tidak hanya dengan modal kharisma, tetapi juga memerlukan skill atau keahlian.

5. Mempertimbangkan efisiensi dan efektivitas program, maka perlu disusun skala prioritas terutama pada program perombakan kurikulum. ${ }^{3}$ Berkaitan dengan proses pembaharuan dalam dunia pondok pesantren, Zamakhsyari Dhofier menolak anggapan dan kesimpulan sebagian kalangan yang menganggap bahwa para kyai menjadi penghambat bagi lajunya proses pembaharuan. Meski kemudian diakui oleh Dhofier bahwa tidak semua pesantren bisa dan mampu melakukan perubahan-perubahan yang sama, bahkan ada kenyataan bahwa perubahan-perubahan yang dilakukan pondok pesantren berjalan dengan tahapan-tahapan yang pelan dan tidak mudah

\footnotetext{
2 Fachrurazi, "Pembaharuan Sistem Pembelajaran Pondok Pesantren (Tradisional Versus Modern)", dalam Jurnal At-Turats, Vol. 10, No. 2, Tahun 2016, hlm. 58-59.

${ }^{3}$ Nurcholish Madjid, Bilik-Bilik Pesantren Sebuah Potret Perjalanan (Jakarta: Paramadina, 1997), hlm. 102
} 
diamati. ${ }^{4}$ Secara umum, para kyai mengambil sikap yang lapang dada dalam menyelenggarakan modernisasi lembaga-lembaga pesantren di tengah-tengah perubahan masyarakat Jawa, tanpa meninggalkan aspek-aspek positif daripada sistem pendidikan Islam tradisional. Mereka juga berkeyakinan bahwa perubahan-perubahan harus diselenggarakan tanpa merusak aspekaspek positif daripada kehidupan pedesaan.

Dalam rangka memodernisir isi dan sistem pendidikan, lembagalembaga pesantren tersebut tetap memelihara hubungannya dengan arus utama daripada tradisi Islam. Pesantren adaptif terhadap berbagai corak pemikiran Islam yang berkembang. ${ }^{5}$ Para kyai tidak mau membuang kerangka besar daripada tradisi keilmuan; walaupun telah melakukan perubahanperubahan yang sangat fundamental dalam bidang-bidang aktivitas sosial, dan dalam aspirasi profesional. ${ }^{6}$ Tulisan ini ingin mengetahui sejauh mana proses pembaharuan di pondok pesantren berlangsung: Aspek apa yang tetap dan apa yang berubah?

\section{B. PEMBAHASAN}

\section{Pengertian Pembaharuan}

Kata pembaharuan merupakan terjemahan dari kata reformation yang bermakna act of improving or changing something. ${ }^{7}$ Kamus Besar Bahasa Indonesia (KBBI) mendefinisikan pembaharuan sebagai proses "perubahan radikal untuk perbaikan di bidang sosial, politik, agama di masyarakat atau negara". ${ }^{8}$ Pembaharuan seringkali dianggap mempunyai kedekatan makna dengan kata 'modern', 'modernisasi', dan 'modernisme'. Istilah modern secara bahasa berarti "baru", "kekinian", "akhir", "up todate" atau semacamnya. Bisa dikatakan sebagai kebalikan dari "lama", "kolot" atau semacamnya. ${ }^{9}$ Zaman modern salah satunya ditandai dengan kemajuan ilmu pengetahuan dan teknologi yang dicapai oleh manusia. ${ }^{10}$

\footnotetext{
${ }^{4}$ Zamakhsyari Dhofier, Tradisi Pesantren: Studi tentang Pandangan Hidup Kyai (Jakarta: LP3ES, 1982), hlm. 173-174

5 Ruswanto, "Pesantren dan Pembaharuan (Study Tentang Asal-usul Pesantren, Pemikirannya, dan Isu Radikalisme Pesantren)", dalam Al-Tadzkiyyah: Jurnal Pendidikan Islam, Volume 7, Mei 2016, hlm. 111.

${ }^{6}$ Zamakhsyari Dhofier, Tradisi Pesantren, hlm. 174-175

${ }^{7}$ Oxford Learner's Pocket Dictionary, 3rd edition (Oxford University Press, 2003), hlm. 360

${ }^{8}$ Anton Mulyono, et.al., Kamus Besar Bahasa Indonesia (Jakarta: Balai Pustaka, 1990), hlm. 735

${ }^{9}$ Ruchman Basori, The Founding Father Pesantren Modern Indonesia: Jejak Langkah K.H. A. Wahid Hasyim (Jakarta: Inceis, 2008), hlm. 11

${ }^{10}$ Ruchman Busari, The Foundng Father, hlm. 12
} 
Harun Nasution mendefinisikan pembaharuan atau modernsisme sebagai berikut:

Modernisme dalam masyarakat Barat mengandung arti fikiran, aliran, gerakan, dan usaha untuk merubah faham-faham, adat-istiadat, institusiinstitusi lama, dan sebagainya, untuk disesuaikan dengan suasana baru yang ditimbulkan oleh kemajuan ilmu pengetahuan dan teknologi. ${ }^{11}$

Sementara itu, Joseph S. Szyliowics mendefinisikan modernisasi:

Modernisasi adalah sebuah proses yang melibatkan transformasi manusia, masyarakat dan budayanya serta memiliki inti kepercayaan fundamental dalam rasionalitas dan pemikiran ilmiah. Modernisasi merupakan suatu proses yang lingkup dan intensitasnya tidak ada yang menyamai, yang melibatkan transformasi masyarakat yang statis dan tradisional menjadi bangsa-bangsa yang secara kontinyu mampu membangkitkan, menyerap, menopang, dan memproses segala bentuk perubahan yang merebak. ${ }^{12}$

Dalam penjelasannya, Mukti Ali mengutarakan bahwa pembaharuan adalah "Suatu usaha untuk mengganti yang jelek dengan yang baik dan mengusahakan yang sudah baik menjadi lebih baik lagi, menurut anggapan kita."13 Lebih lanjut Mukti Ali memberi penegasan sebagai berikut:

Usaha untuk mengadakan perobahan dan pembaharuan bukan berarti bahwa apa yang akan dirobah dan diperbaharui itu sama sekali jelek. Tetapi karena kesadaran kemajuan teknologi dan komunikasi, dengan makin meningkatnya kebutuhan hidup, maka bagi kaum agama, apalagi ummat Islam, tentu akan kembali kepada ajaran agamanya, apa yang dikatakan oleh agamanya, dalam hal ini agama Islam, dalam soal-soal hidup dan kehidupan yang selalu mengalami perobahan ini. Pendidikan agama itu harus menjawab. ${ }^{14}$

Berdasarkan beberapa penjelasan-penjelasan di atas, pembaharuan dapat dipahami sebagai sebuah proses perubahan secara mendasar, baik pada perbaikan atau penyempurnaan sistem sosial, politik, bahkan agama dan juga pendidikan atau negara tertentu, menuju keadaan yang lebih baik. Pembaharuan setidak-tidaknya mengandung lima hal pokok. Pertama, adanya perubahan. Kedua, proses pembaharuan dilakukan secara

\footnotetext{
${ }^{11}$ Harun Nasution, Pembaharuan dalam Islam; Sejarah Pemikiran dan Gerakan (Jakarta: Bulan Bintang, 1992), hlm. 11

12 Joseph S. Szyliowics, Pendidikan dan Modernisasi di Dunia Islam, Alih Bahasa: Achmad Jainuri (Surabaya: Al-Ikhlas, 2001), hlm. 4

${ }^{13}$ Team Penyusun BKP3, Peranan Pondok Pesantren dalam Pembangunan (Jakarta: PT. Paryu Barkah), hlm. 3

${ }^{14}$ Team Penyusun BKP3, Peranan, hlm. 13
} 
mendasar. Ketiga, mengarah pada perbaikan (kualitas). Keempat, objeknya jelas. Kelima, terjadi pada wilayah tertentu. ${ }^{15}$

\section{Tujuan Pembaharuan}

Institusi pendidikan, baik bercorak keagamaan maupun tidak, selalu tidakpernah bisa terlepas dari konteks dan perkembangan lingkungan sekitar. Sebagaimana lembaga pendidikan lainnya, pondok pesantren mengalami perkembangan dan pembaharuan agar senantiasa dapat menyesuaikan diri dengan kemajuan ilmu pengetahuan dan teknologi. "Walaupun telah terjadi dinamika dalam dunia pesantren, pesantren berada pada fungsi aslinya, yakni sebagai lembaga pendidikan guna mencetak tenaga ahli keagamaan."16 "Perubahan bentuk pondok pesantren bukan berarti sebagai pondok pesantren yang kehilangan kekhasannya. Dalam hal ini pondok pesantren tetap merupakan lembaga pendidikan Islam yang tumbuh dan berkembang dari masyarakat untuk masyarakat." 17 "...Bahwa dalam membangun masa depannya, pesantren berdiri dengan teguh di atas landasan tradisi lampaunya." 18

Nurcholish Madjid menguraikan urgensi pondok pesantren untuk selalu merespon kemajuan zaman sebagai berikut:

Pesantren diwajibkan oleh tuntutan-tuntutan hidup anak didiknya kelak dalam kaitannya dengan perkembangan zaman untuk membekali mereka dengan kemampuan-kemampuan nyata yang dapat melalui pendidikan atau pengajaran pengetahuan secara memadai. Di bagian inipun sebagaimana layaknya yang terjadi sekarang harus tersedia kemungkinan mengadakan pilihan-pilihan jurusan bagi anak didik sesuai dengan potensi buat mereka. Jadi tujuan pendidikan pesantren kiranya berada di sekitar terbentuknya manusia yang memiliki kesadaran setinggi-tingginya akan bimbingan Islam. Weltanschuung yang bersifat menyeluruh, dan diperlengkapi dengan kemampuan setinggi-tingginya untuk mengadakan responsi terhadap tantangan-tantangan dan tuntutan-tuntutan hidup dalam konteks ruang dan waktu yang ada di Indonesia dan dunia abad sekarang. ${ }^{19}$

Dinamika dan perubahan sosial yang sangat cepat tentu memerlukan respon yang tepat. Kemajuan materiil yang dihasilkan oleh dunia modern dewasa ini akan menjadi suatu ancaman yang serius bagi martabat dan keutuhan individu. Oleh karena itulah, pesantren memiliki

${ }^{15}$ Ruchman Basori, The Founding Father, hlm. 15

16 Haidar Putra Daulay, Sejarah Pertumbuhan dan Pembaruan Pendidikan Islam di Indonesia (Jakarta: Kencana, 2009), hlm. 74

${ }^{17}$ M. Bahri Ghazali, Pesantren Berwawasan Lingkungan (Jakarta: Prasasti, 2002), hlm. 14

${ }^{18}$ Zamakhsyari Dhofier, Tradisi Pesantren, hlm. 176

${ }^{19}$ Haidar Putra Daulay, Sejarah Pertumbuhan, hlm. 75 
peran strategis untuk mengisi kekosongan yang dihasilkan oleh dunia modern ini dengan menitikberatkan perhatiannya pada usaha untuk membangun mental dan kepribadian manusia-manusia modern. Jika kekosongan jiwa dan mental ini tidak diisi, "kekosongan ini akan diisi oleh agama lain, atau setidak-tidaknya ketrombolan kebudayaan lain." ${ }^{20}$

Persoalan mental inilah bagi Mukti Ali, mula-mula yang harus diperbaharui. Dalam kaitan pembangunan mental inilah, maka sistem pendidikan dan pengajaran di pesantren harus diintegrasikan dengan kebutuhan masyarakat. Hal ini didukung pada kenyataan bahwa pada umumnya pondok pesantren berada di luar kota atau desa-desa sehingga keberadaanya akan mampu meningkatkan dan memajukan kehidupan masyarakat sekitarnya. Selain itu juga, pondok pesantren adalah tempat pendidikan yang paling utama dalam menanam dan menyiarkan ajaran Islam di kalangan masyarakat Indonesia. Pondok pesantren juga dinilai sebagai sebuah sub kultur pendidikan di Indonesia sehingga pembaharuan yang dilaksanakan akan menberikan warna dan corak masyarakat yang unik. Di samping itu juga, pondok pesantren merupakan prototype model pendidikan yang ideal bagi bangsa Indonesia yang di dalamnya diseimbangkan antara ranah kognitif, afektif, dan psikomotorik. ${ }^{21}$

Pada akhirnya, pembaharuan pesantren akan menjadi tolak ukur sejauh mana pesantren yang merupakan lembaga pendidikan Islam asli (indigenous) nusantara yang bercorak tradisional dapat berdialektika dalam merespons perkembangan serta dinamika perkembangan dunia luar. Respons pondok pesantren akan menjadi kunci eksisitensi pondok pesantren.

\section{Corak Pesantren}

Pesantren berasal dari kata santri, yang dengan awalan pe dan akhiran an yang berarti tempat tinggal para santri. Professor Johns berpendapat bahwa istilah santri berasal dari bahasa Tamil, yang berarti guru mengaji, sedang C.C. Berg berpendapat bahwa istilah tersebut berasal dari bahasa India shastri yang berarti orang-orang yang tahu buku-buku suci Agama Hindu. Kata shastri berasal dari shastra yang berarti bukubuku agama atau buku-buku tentang ilmu pengetahuan. ${ }^{22}$

Pesantren merupakan salah satu lembaga pendidikan yang tertua di Indonesia. Jika kita telusuri dalam sejarah pendidikan Indonesia ke masa

${ }^{20}$ Suparlan Suryopratondo dkk., Kapita Selekta Pondok Pesantren (Jakarta: PT. Paryu Barkah, 1976), hlm. 49

${ }^{21}$ Abuddin Natta, Kapita Selekta Pendidikan Islam (Jakarta: Angkasa, 2003), hlm. 115

22 Zamakhsyari Dhofier, Tradisi Pesantren, hlm. 18 
lampau, didapati "bahwa pesantren merupakan salah satu bentuk indegenous culture atau bentuk kebudayaan asli bangsa Indonesia." 23 Lembaga pendidikan dengan pola kyai, santri, dan asrama telah dikenal dalam kisah dan cerita klasik rakyat di pulau Jawa. Model pendidikan pesantren telah lebih dahulu dikenal saat masa agama Hindu Budha. Para ulama Islam, kemudian menggunakan model pendidikan pesantren karena sudah banyak tumbuh tersebar dan mengakar di tengah-tengah masyarakat.

Dalam sejarah perjuangan Kemeredekaan Indonesia, pondok pesantren juga turut andil dalam perjuangan melawan penjajahan Belanda. Lembaga-lembaga pesantren di pedesaan memegang peranan politik perlawanan yang sengit terhadap Belanda. Para kyai mengobarkan semangat jihad dan perlawanan terhadap para penjajah. Usaha perlawanan dari para kyai di pesantren merupakan upaya untuk menjadi benteng perlindungan agama Islam. Peranan pondok pesantren kemudian berlanjut saat masa keangkitan nasional, kemerdekaan Indonesia, dan saat-saat mempertahankan tegaknya Negara Kesatuan Republik Indonesia.

Ada beberapa ciri umum sebuah lembaga pendidikan pantas disebut sebagai pesantren. Dhofier merumuskan setidaknya lima hal yang menjadi ciri umum pesantren yaitu, pertama, ada pondok atau asrama. Kedua, masjid sebagai tempat pendidikan dan pengajaran. Ketiga, pengajaran kitab-kitab Islam klasik. Keempat, Santri. Kelima, kyai. ${ }^{24}$ Dari kelima hal di atas, kedudukan kyai amatlah penting dalam pesantren. Kyai adalah tokoh sentral dalam pesantren. Kebanyakan pesantren didirikan oleh seorang kyai dengan dana mandiri atau bisa diartikan bahwa pesantren adalah miik seorang kyai. Sehingga suatu pesantren identik dengan kyainya, bahkan sebuah pesantren dikenal serta maju dan mundurnya pesantren salah satunya adalah terletak pada faktor wibawa dan keilmuan seorang kyai yang menjadi pemimpin sekaligus pendidik di pesantren tersebut. Kharisma dan otoritas keilmuan kyai menjadi keunggulan dan daya tartik masyarakat terhadap suatu pondok pesantren.

\section{Pembaharuan Sistem Pendidikan Pesantren.}

Setidaknya ada empat level pembaharuan dalam sistem pendidikan Islam di Indonesia, termasuk pesantren di dalamnya. ${ }^{25}$ Pertama, level kelembagaan. Kedua, level substansi isi kurikulumnya. Ketiga, level metodologis. Keempat, level fungsi. Dari keempat level pembaharuan

${ }^{23}$ Team Penyusun BKP3, Peranan, hlm. 20

${ }^{24}$ Zamakhsyari Dhofier, Tradisi Pesantren, hlm. 44-55

${ }^{25}$ Ruchman Busari, The Foundng Father, hlm. 29-30 
tersebut, yang terjadi adalah pembaharuan pada level kelembagaan, kurikulum, dan metodologi pengajaran. Sementara pembaharuan tentang fungsi jarang sekali terjadi. Artinya meski pembaharauan adalah keniscayaan dalam sistem pendidikan pesantren, fungsi dan tujuan utama pesantren sebagai tempat untuk transfer ilmu-ilmu keagamaan, mencetak ulama dan ahli agama yang tafaqquh fiddin dan mampu mengkader insan insan yang mutafaqquh fiddin.

\section{a. Pembaharuan Kelembagaan}

Pembaharuan pada level kelembagaan memungkinkan untuk memilih atas dua pilihan yaitu menyesuaikan lembaga yang sudah ada atau mendirikan lembaga baru. Dalam pengertian lain; kelembagaan pesantren mencontoh sepenuhnya model pendidikan Barat atau mengadakan penyesuaian sesuai dengan kebutuhan dan kemapuan. Secara faktual ada tiga tipe kelembagaan pesantren yang berkembang di masyarakat sebagai berikut: ${ }^{26}$

1). Pesantren Tradisional (salafi)

Pesantren model ini semata-mata mengajarkan kitab-kitab klasik melalui model halaqoh, sorogan, wetonan, bandongan dengan menggunakan bahasa Arab di masjid atau surau. Kyai memegang peranan yang sangat penting dalam proses pengajarannya.

2). Pesantren Modern (khalafi)

Pesantren model ini meninggalkan model pembelajaran tradisional dan mengganti seluruhnya dengan model klasikal dalam bentuk sekolah dan madrasah, bahkan ada yang mendirikan perguruan tinggi. Kyai berlaku sebagai koordinator pelaksanaa pembelajaran. Kurikulum mengikuti kurikulum pendidikan nasional.

3). Pesantren Komprehensif

Pesantren model ini menggabungkan antara model yang tradisional dan modern. Artinya, di dalamnya diterapkan kurikulum pengajaran kitab-kitab klasik di samping juga pengajaran kurikulum lewan madrasah dan sekolah. Kyai dapat mengajarkan kitab-kitab klasik di masjid juga bisa menjadi ustadz yang mengajar di ruang-ruang kelas.

Dalam perkembangannya beberapa pola pesantren ditinjau dari bangunan fisik kelembagaan. Berdasarkan bangunan fisik ada lima

\footnotetext{
${ }^{26}$ M. Bahri Ghazali, Pesantren Berwawasan Lingkungan, hlm. 14.
} 
pola pesantren. Pertama, masjid dan rumah kyai. Kedua, masjid, rumah kyai, dan pondok. Ketiga, masjid, rumah kyai, pondok, madrasah. Keempat, masjid, rumah kyai, pondok, madrasah, tempat keterampilan. Kelima, masjid, rumah kyai, pondok, madrasah, tempat keterampilan, sekolah umum, universitas, gedung olahraga. ${ }^{27}$

Pembaharuan kelembagaan selain mencakup soal bentuk pesantren, juga mencakup pembaharaun dalam bidang administrasi dan organisasi. Tidak dapat disangkal bahwa, pesantren didirikan atas prakarsa dan usaha pribadi dari kyai yang didukung oleh keluarganya. Akibat logis yang ditimbulkan adalah bahwa kemajuan dan kemunduran pesantren akan sangat tergantung individu kepemimpinan kyai. Oleh karena itu perlu dilakukan pembaharuan kelembagaan dalam bentuk yayasan sehingga ada transformasi dari kepemimpinan individual kyai menjadi kepemimpinan kolektif 28 atau bentuk lainnya sehingga keberlangsungan pesantren dapat lebih terjamin. $^{29}$

\section{b. Pembaharuan Kurikulum}

Pada mulanya pesantren hanya mengajarkan kitab-kitab klasik karangan ulama-ulama penganut mazhab syafi'iyah. Pesantren dalam hal ini memiliki tujuan untuk mencetak ulama yang ahli dalam bidang agama. Keseluruhan kitab-kitab klasik yang diajarkan digolongkan ke dalam 8 kelompok: nahwu dan shorof; fiqh; ushul fiqh; hadis; tafsir; tauhid; tasawuf dan etika; tarikh dan balaghoh. ${ }^{30}$ Homogenitas kitabkitab yang diajarkan menghasilkan kesamaan corak dan pandangan hidup dalam dunia pesantren.

Mukti Ali menekankan tentang pentingnya pembaharuan kurikulum ini, hal ini dilatari bahwa selama ini pembaharuan yang terjadi adalah hanya sebatas pembaharuan yang bersifat vertikal atau kelembagaan belum menyasar pembaharuan yang bersifat horizontal atau kurikulum dan metodologi pengajaran. Perubahan horizontal yang menyasar kurikulum pengajaran diharapkan berorientasi kepada kebutuhan masyarakat. ${ }^{31}$ Dicontohkannya tentang universitasuniversitas di barat yang pada awal mulanya didirikan untuk misi zending penyebaran agama Kristen, namun lama-kelamaan karena

\footnotetext{
${ }^{27}$ Haidar Putra Daulay, Sejarah Pertumbuhan, hlm. 66

${ }^{28}$ Muhamad Ramli, "Manajemen dan Kepemimpinan Pesantren”, dalam Jurnal Al-Falah, Vol. XVII, No. 32 Tahun 2017, hlm 125-126.

${ }^{29}$ Team Penyusun BKP3, Peranan, hlm. 28

${ }^{30}$ Zamakhsyari Dhofier, Tradisi Pesantren, hlm. 50

${ }^{31}$ Team Penyusun BKP3, Peranan, hlm. 11-13
} 
kebutuhan masyarakat yang berkembang, maka universitasuniversitas mengembangkan kurikulum lain tidak hanya pengajaran bermuatan agama.

Sedangkan menurut kurikulumnya ada lima pola pesantren. Pertama, pelajaran kitab-kitab klasik dengan sistem sorogan dan wetonan. Kedua, pengajaran dengan sistem klasikal dan non klasikal. Ketiga, disamping mendapat materi agama, santri juga mendapat materi pengetahuan umum, keterampilan, dan organisasi. Keempat, menitikberatkan pada pengajaran keterampilan selain pengajaran agama Islam. Kelima, pesantren yang mengajarkan kitab-kitab klasik, madrasah, keterampilan, sekolah umum, dan perguruan tinggi. ${ }^{32}$ Kebanyakan pesantren berjalan dan berkembang dengan mengambil salah satu pola di atas.

Tentu saja masalah kurikulum tidak dapat dilepaskan dari guru yang mengajar serta sarana-prasarana yang ada. Yang tidak menutup peluang semakin masuknya jumlah pengajar yang terdidik lebih baik dan lulusan universitas-universitas umum. Fenomena ini memiliki efek ganda; di satu sisi akan mempercepat proses pembaharuan di lingkungan pesantren, namun di sisi lain akan mengancam nilai-nilai dan pandangan hidup khas pesantren. Jika hal ini terjadi maka akan menimbulkan reaksi dari sebagian pihak untuk kembali ke tradisi lama pesantren. ${ }^{33}$ Pesantren perlu mengembangkan kurikulum (isi pendidikan) yang menuju ke arah keunggulan sesuai visi, misi, dan tuntutan perkembangan kebutuhan masyarakat, dengan memanfaatkan kemajuan iptek yang berkembang. ${ }^{34}$

\section{c. Pembaharuan Metodologi Pengajaran}

Pengajaran di pesantren pada mulanya dilaksanakan di masjid atau surau dengan sistem melingkar berkelompok dibawah bimbingan seorang kyai yang disebut halaqoh, jadi pengajaran tidak berlangsung di dalam kelas. Secara umum dikenal dua model pengajaran di pesantren, yaitu sorogan dan bandongan atau weton.

Sistem sorogan merupakan sistem individual yang biasanya diberikan kepada santri-santri baru yang masih memerlukan bimbingan khusus. Sitem sorogan ini merupakan sistem yang paling

\footnotetext{
${ }^{32}$ Haidar Putra Daulay, Sejarah Pertumbuhan, hlm. 67-68

${ }^{33}$ Zamakhsyari Dhofier, Tradisi Pesantren, hlm. 175

${ }^{34}$ HM Atho Mudzhar, "Pesantren Transformatif: Respon Pesantren Terhadap Perubahan Sosial," dalam Jurnal Penelitian Pendidikan Agama dan Keagamaan, Volume 6 Nomor 2, Arpil-Juni 2008, hlm. 14.
} 
sulit karena memerlukan kesabaran, kerajianan, ketaatan, dan disiplin pribadi santri. ${ }^{35}$ Dalam sistem sorogan santri biasanya hanya terdiri dua atau tiga orang santri menghadap pada kyai dengan men-yorogkan kitab tertentu. Santri membacakan kitab tersebut kepada kyai lalu kyai membetulkan jika terjadi kesalahan. ${ }^{36}$ Sistem sorogan ini adalah langkah awal untuk memtangkan diri sebelum mengikuti pendidikan selanjutnya di pesantren. Model sorogan ini juga cocok untuk mencetak ulama karena memungkinkan seorang kyai untuk mengawasi santrinya secara penuh dan maksimal. ${ }^{37}$

Sedangkan sistem wetonan dan bandongan adalah merupakan sistem pengajaran utama di dalam pesantren, di mana sekelompk santri dalam jumlah banyak duduk di sekeliling kyai. ${ }^{38}$ Kyai membacakan suatu kitab kemudian para santri mendengarkan, menerjemahkan, menerangkan, membuat catatan, dan mengulas buku-buku yang dibacakan oleh kyai. Hanya santri yang telah menguasai sistem sorogan yang dapat memetik keuntungan dari sistem bandongan ini. ${ }^{39}$ Metode lain yang dipakai di pesantren adalah hafalan di mana materi-materi pelajaran diharuskan untuk dihafal oleh para santri. ${ }^{40}$

Namun kini, banyak pesantren yang telah melakukan pembaharuan metode pengajaran yang tidak hanya menggunakan metode tradisional seperti yang disebutkan di atas. Model klasikal dengan pembelajaran di dalam kelas kini mulai dilakukan di pesantren. Selain itu juga model pelatihan-pelatihan, dan bengkelmagang juga mulai diperkenalkan di lingkungan pesantren. Metode pengajaran ini dilakukan agar para santri tidak hanya menguasai ilmuilmu agama tetapi juga memiliki kecakapan hidup yang akan berguna dalam kehidupannya kelak. Terlebih kini di era kemajuan teknologi, pesantren harus mampu menggunakan teknologi dalam sistem dan metode pembelajarannya. ${ }^{41}$

\footnotetext{
${ }^{35}$ Zamakhsyari Dhofier, Tradisi Pesantren,hlm. 18

${ }^{36}$ M. Bahri Ghazali, Pesantren Berwawasan Lingkungan, hlm 29

${ }^{37}$ Zamakhsyari Dhofier, Tradisi Pesantren,hlm. 29

${ }^{38}$ Haidar Putra Daulay, Sejarah Pertumbuhan, hlm. 69

${ }^{39}$ Zamakhsyari Dhofier, Tradisi Pesantren,hlm. 29

${ }^{40}$ Haidar Putra Daulay, Sejarah Pertumbuhan, hlm. 69

${ }^{41}$ Mohammad Arif, Perkembangan Pesantren di Era Teknologi," dalam Jurnal Pendidikan Islam UIN Sunan Gunung Djati Bandung, Vol. XXVIII No. 2, 2013/1434, hlm. 316-317.
} 


\section{SIMPULAN}

Respons pondok pesantren terhadap perubahan berbeda-beda. Umumnya perubahan dalam pondok pesantren berlangsung dalam tahapan yang pelan dan sukar diamati. Kyai memegang peran penting dalam proses pembaharuan dalam kehidupan pondok pesantren. Secara umum, para kyai mengambil sikap yang lapang dada dalam menyelenggarakan modernisasi lembaga-lembaga pesantren di tengah-tengah perubahan masyarakat Jawa, tanpa meninggalkan aspek-aspek positif daripada sistem pendidikan Islam tradisional.

Setidaknya ada empat level pembaharuan dalam sistem pendidikan Islam di Indonesia, termasuk pesantren di dalamnya. Pertama, level kelembagaan. Kedua, level substansi isi kurikulumnya. Ketiga, level metodologis. Keempat, level fungsi. Dari keempat level pembaharuan tersebut, yang terjadi adalah pembaharuan pada level kelembagaan, kurikulum, dan metodologi pengajaran. Sementara pembaharuan tentang fungsi pondok pesantren sebagai jarang sekali terjadi. Artinya meski pembaharauan adalah keniscayaan dalam sistem pendidikan pesantren, fungsi dan tujuan utama pesantren sebagai tempat untuk transfer ilmu-ilmu keagamaan, mencetak ulama dan ahli agama yang tafaqquh fiddin dan mampu mengkader insan insan yang mutafaqquh fiddin.

\section{DAFTAR PUSTAKA}

Arif, Mohammad. 2013. "Perkembangan Pesantren di Era Teknologi," dalam Jurnal Pendidikan Islam UIN Sunan Gunung Djati Bandung, Vol. XXVIII No. 2, 2013/1434.

Basori, Ruchman. 2008. Founding Father Pesantren Modern Indonesia Jejak Langkah K.H. A. Wahid Hasyim. Jakarta: Inceis.

Daulay, Haidar Putra. 2009. Sejarah Pertumbuhan dan Pembaruan Pendidikan Islam di Indonesia. Jakarta: Kencana.

Dhofier, Zamakhsyari. 1982. Tradisi Pesantren Studi tentang Pandangan Hidup Kyai. Jakarta: LP3ES.

Fachrurazi. 2016. "Pembaharuan Sistem Pembelajaran Pondok Pesantren (Tradisional Versus Modern)", dalam Jurnal At-Turats, Vol. 10, No. 2, Tahun 2016.

Ghazali, M. Bahri. 2002. Pesantren Berwawasan Lingkungan. Jakarta: Prasasti. 
Hambali. 2014. "Globalisasi dan Pendidikan Pesantren" dalam Jurnal AlTa'lim, Vol. 13, No. 2, Juli 2014.

Junaidi, Junaidi. "Model Pendidikan Multikultural." Al-Insyiroh: Jurnal Studi Keislaman 2.1 (2018): 57-72.

Madjid, Nurcholish. 1997. Bilik-Bilik Pesantren Sebuah Potret Perjalanan. Jakarta: Paramadina.

Moelijono, Anton M., dkk. 1990. Kamus Besar Bahasa Indonesia. Jakarta: Balai Pustaka.

Mudzhar, HM Atho. 2008."Pesantren Transformatif: Respon Pesantren Terhadap Perubahan Sosial," dalam Jurnal Penelitian Pendidikan Agama dan Keagamaan, Volume 6 Nomor 2, Arpil-Juni 2008.

Nasution, Harun. 1992. Pembaharuan dalam Islam; Sejarah Pemikiran dan Gerakan. Jakarta: Bulan Bintang.

Nata, Abuddin (ed.). 2003. Kapita Selekta Pendidikan Islam. Bandung: Angkasa.

Oxford Learner's Pocket Dictionary 3rd ed. 1982. Oxford University Press. Ramdhan, Tri Wahyudi. "Islam Nusantara: Pribumisasi Islam ala NU." AlInsyiroh: Jurnal Studi Keislaman 2.1 (2018): 73-91.

Ramli, Muhamad . 2017. "Manajemen dan Kepemimpinan Pesantren", dalam Jurnal Al-Falah, Vol. XVII, No. 32 Tahun 2017.

Ruswanto. 2016. "Pesantren dan Pembaharuan (Study Tentang Asal-usul Pesantren, Pemikirannya, dan Isu Radikalisme Pesantren)", dalam AlTadzkiyyah: Jurnal Pendidikan Islam, Volume 7, Mei 2016.

Suryopratondo, Suparlan dkk. 1976. Kapita Selekta Pondok Pesantren. Jakarta: Paryu Barkah.

Szyliowics, Joseph S. 2001. Pendidikan dan Modernisasi di Dunia Islam, Alih Bahasa: Achmad Jainuri. Surabaya: Al-Ikhlas.

Team Penyusun BKP3. 1976. Peranan Pondok Pesantren dalam Pembangunan. Jakarta: Paryu Barkah. 